\title{
Response Surface Analysis of the Compressive Strength of Self-Compacting Concrete Incorporating Metakaolin
}

\author{
Ayobami Busari ${ }^{i^{*}}$, Bamidele Dahunsi ${ }^{2}$, Joseph Akinmusuru', \\ Tolulope Loto ${ }^{3}$, Samuel Ajayi ${ }^{4}$ \\ 1 Department of Civil Engineering, Covenant University, Ogun State, Nigeria \\ 2 Department of Civil Engineering, University of Ibadan, Oyo State, Nigeria \\ 3 Department of Mechanical Engineering, Covenant University, Ogun State, Nigeria \\ 4 Nigerian Building and Road Research Institute, Ota, Ogun State, Nigeria \\ * Corresponding author's e-mail: ayobami.busari@covenantuniversity.edu.ng
}

\begin{abstract}
This research developed a mathematical model and optimization of materials for the development of metakaolin self-compacting concrete. This is in a bid to reduce the overall material quantity and cost towards sustainable infrastructural construction. To achieve the aim of this research, Response Surface Analysis (RSM) was used. Kaolinitic clay was De-hydroxylated at $750^{\circ} \mathrm{C}$ to form metakaolin. This was used as a partial replacement for cement at $0 \%, 5 \%, 10 \%, 15 \%, 20 \%$ and $25 \%$ weight of Portland limestone cement. Both strength and rheology properties of the developed metakaolin self-compacting concrete were assessed. To this end, slump flow, L-Box test and V-funnel test were carried out alongside the compressive strength using relevant standard. The result of the research revealed that at $15 \%$ addition of metakaolin the slump flow, passing ability and filling ability was unsatisfactory according to EFNARC standard. From the numerical optimization of the compressive strength, the maximum predicted compressive strength of $44.35 \mathrm{~N} / \mathrm{mm}^{2}$ was obtained. At a low value of metakaolin addition (5-15\%), the compressive strength increased as the age of the concrete increased from 3-150 days. The age with the optimum mechanical strength formation was 110 days with metakaolin addition of $52.73 \mathrm{~kg}$. The result of this research provide a database for Engineers, Researchers and Construction workers on the optimum metakaolin required to achieve satisfactory mechanical strength in metakaolin self-compacting concrete.
\end{abstract}

Keywords. response surface analysis, metakaolin, self-compacting concrete, sustainable infrastructure.

\section{INTRODUCTION}

Cement is one of the most commonly used construction materials in the world and its price has risen at an alarming rate over the last few years. This high increase in the cost of cement has led to a reduction in concrete construction in underdeveloped and developing countries. This calls for the incorporation of natural nonexpensive material as a substitute for cement. Metakaolin is a naturally occurring material with pozzolanic properties, capable of replacing a certain percentage of cement when used in production of self-compacting concrete (SCC).
Self-compacting concrete is a recent development in the concrete construction industry. It is asserted as being the way forward in concrete production based on its numerous advantages [Ouchi and Hibino 2000]. Focus on sustainability in line with the application of self-compacting concrete was done by [Tarun and Naik 2012; Grdić et al. 2008; Navid et al. 2016; Hesami et al., 2016; Aggarwal et al., 2008; Okamura and Ouchi 2003] to mention a few. The use of cement alone as a binder in self-compacting concrete leads to thermal crack. In an attempt to reduce the incidence of the crack and reduce the cost of SCC production, the use of metakaolin as 
a supplementary material was adopted based on its unique properties.

Metakaolin is obtained when Kaolinitic clay is heated to a temperature of $650-900{ }^{\circ} \mathrm{C}$. At this temperature, an endothermic reaction takes place to form metakoalin, according to Justice et al. (2005). The reaction of this material with modified cement paste micro structure is similar to the pozollanic properties of silica fumes, rice husk ash, fly ash etc. [Shivram and Nagesh 2007]. In line with the use of other cementitious material, the use of metakaolin was found to form a good combination in concrete production [Kamaruddin 1991, Sabir et al. 2001, Nabil 2006, Jiping and Albinas 2009, Jian-Tong and Zongjin 2002, Hemant 2011, Vejmelková et al. 2010, Badogiannis et al. 2004 and Arikan et al. 2001].

The use of this mineral material was found to improve the durability, strength and cohesion of concrete structures [Justice et al. 2005, Kong and Orbison 1987]. Studies showed that the introduction of $20 \%$ of metakaolin improves the strength of concrete (Shepur 2014). However, there is a need to assess the optimum quantity of this material needed in self-compacting concrete. To this end, Response Surface Analysis Method (RSM) was adopted in this study.

Response Surface Methodology (RSM) is a collection of mathematical and statistical techniques useful for the modelling and analysis of problems in which a response of interest is influenced by several variables [Myers and Montgomery, 1995; Akinoso et al., 2011]. It is a powerful tool used for the optimization of chemical reactions or engineering processes.

This unique tool was used to assess the effect of metakaolin and Self-Compacting Concrete in concrete technology.

The aim of making concrete affordable and improving green construction motivated this research. RSM was used to provide a data base on the optimum strength achievable using metakaolin in self-compacting concrete for engineers, researchers and construction workers.

\section{MATERIAL AND METHODS}

Locally available Portland limestone cement (rapid hardening cement) conforming to NIS (2003) was used in the study. The metakaolin used as a supplementary material was sourced from south western Nigeria. The kaolin used for this research was sourced from the same geographic location as in the study of Ogundiran and Ikotun (2016) and Labiran (2016). Scanning Electron Microscopy was used in assessing the chemical composition, surface structure and particleometry of the metakaolin. The chemical composition of the metakaolin and the cement used is as shown in Table 1. Coarse and fine aggregate of size $4.5 \mathrm{~mm}$ and $19.5 \mathrm{~mm}$ were used in the research. A polycarboxylate-based high-range water reducing admixture (HRWRA), super-plasticizer was used in this research according to EFNARC (2002).

Metakaolin was used as a replacement for the Portland limestone cement at $0 \%, 5 \%, 10 \%, 15 \%$, $20 \%$ percentage of the dry weight of the cement. The total paste volume was kept constant for all SCC mixtures. The flowing ability, passing ability and the slump flow were assessed using the L-Box, V-funnel and the slump flow apparatus. The results obtained were compared with the standards of EFNARC. The strength properties were assessed using the compressive strength and split tensile, this was done according to ASTM C192 specifications.

Response surface methodology (RSM) was adopted in the design of experimental combinations. It also used to quantify the relationship between the controllable input parameters and the obtained response surfaces.

Analysis of variance (ANOVA) was performed for the data obtained in this experiment for different replacement as the age increased. The interaction between the input variables (cement, age and metakaolin) and the response of different regression models developed for compressive strength was investigated.

\section{RESULTS AND DISCUSSION}

\section{Rheological properties of the fresh concrete}

The segregation resistance of the selfcompacting concrete was determined by using the V-funnel

test. According to EFNARC (2002) specification the acceptable criteria for the $\mathrm{V}$-funnel result is between 6 and 12 seconds. On the basis of these criteria, the SCC mix with metakaolin addition from $15 \%$ and more did not satisfy this criterion (Figure 1). This may be due to the fact that the incorporation of high metakaolin content affected the viscosity of the mix. 


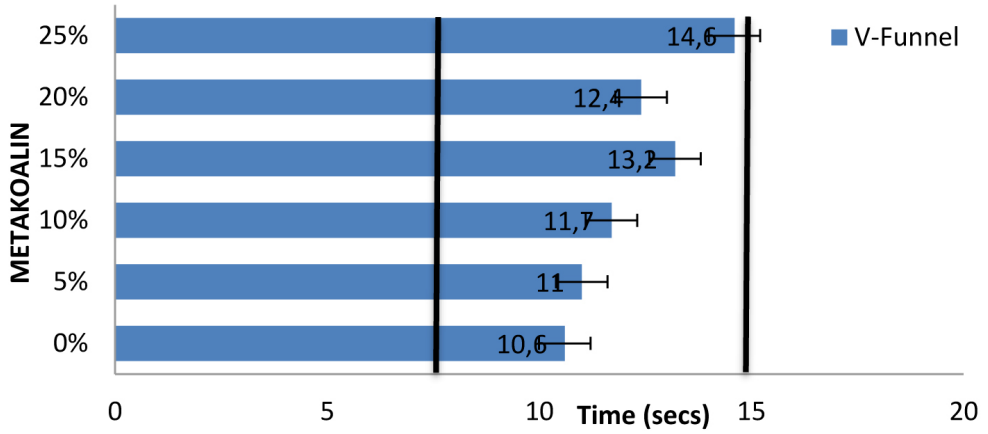

Figure 1. V-Funnel

L-box height ratios were measured and the corresponding outcomes were presented in Table 1. The result followed a similar trend with the slump flow test. At $15 \%$ percentages and greater addition of metakaolin, the L-box result became unsatisfactory too, as seen in Figure 2.

The slump flow test was used to determine the ability of the SCC to flow in a nonrestricted condition. The factors affecting the results of the $\mathrm{T}_{50}$ time are the amount, shape and size distribution of aggregates and also the viscosity and amount of paste, in accordance with Uygunoglu and Topçu [2005]. The mix with the lowest $\mathrm{T}_{50}$ time is the SCC with no metakaolin addition (Table 1). On the basis of the result, a direct relationship was established with metakaolin quantity and $\mathrm{T}_{50}$ time based on the EFNARC (2002) specification.

\section{Strength properties}

The result of the analysis showed that the addition of metakaolin to concrete resulted in an improved strength till $10 \%$ replacement. Upon further addition, the compressive strength began to reduce. The highest strength across all ages was recorded at $10 \%$ addition of metakaolin. However, at $15 \%$ and $20 \%$ (Figure 3 ) the strength was still higher than the control. However, a decrease in the compressive strength was noticed when

Table 1. Slump flow

\begin{tabular}{|c|c|}
\hline $\begin{array}{c}\text { Metakaolin percentage } \\
\text { replacement }\end{array}$ & $T_{50}(\mathrm{Sec})$ Slump flow \\
\hline $0 \%$ (control mix) & 3.5 \\
\hline $5 \%$ replacement & 4.0 \\
\hline $10 \%$ replacement & 4.4 \\
\hline $15 \%$ replacement & 5.6 \\
\hline $20 \%$ replacement & 7.3 \\
\hline $25 \%$ replacement & 8.1 \\
\hline
\end{tabular}

compared with $0 \%$ metakaolin at the percentages higher than $20 \%$.

The predicted R-Squared of 0.766 is in reasonable agreement with the "Adjusted RSquared" of 0.809 as shown in Table 2. "Adeq Precision" measures the signal to noise ratio. A ratio greater than 4 is desirable. The model ratio of 15.712 indicates an adequate signal. This model can be used to predict the effect of metakaolin, cement and age on the compressive strength of metakaolin concrete.

The model equation in terms of actual factor is given in equation 1 as follows;

Compressive Strength $=-184.70+1.60 \mathrm{~A}-$

$-0.14 B+813.61 C-1.61 A^{2}+1.77 B^{2}-$

$-768.30 C^{2}+4.08 A \cdot B-3.19 A \cdot C-0.35 B \cdot C$

where: $A$-age,

$$
\begin{aligned}
& B \text { - metakaolin, } \\
& C \text { - cement. }
\end{aligned}
$$

The results indicate that the addition of cement and metakaolin had a positive effect on the strength properties of the developed self-compacting concrete, as seen in equation 1 .

The normal plot of residuals on the experimental run shows a close fit with the predicted values. Figure 4 shows no outlier in the experimental runs.

The predictability plot of the model to account for future occurences is as shown in Figure 4. The predicted data points scatter round the actual data points showing less overfitting and gave a predicted R-squared value of 0.767 .

\section{Synergetic effect of input parameters on compressive strength}

The Figures 5 and 6 show the contour plots and 3D for determining the effects of Age and Metakaolin against the compressive strength. At low value of Metakaolin, the compressive 


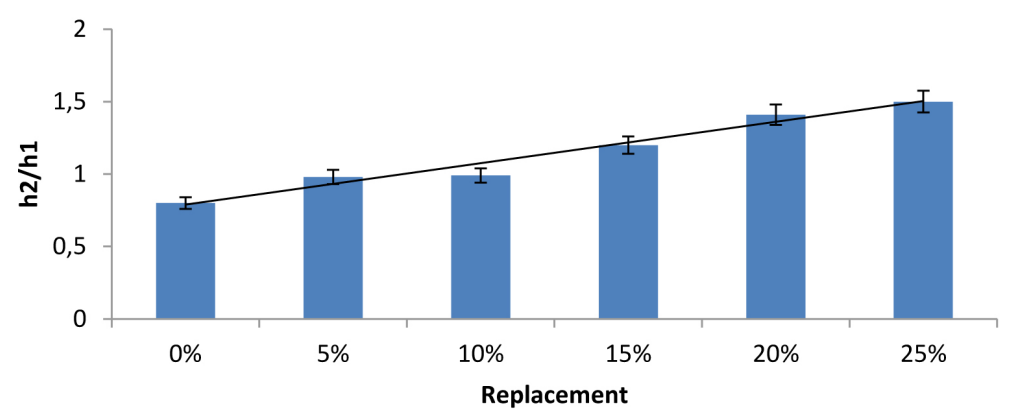

Figure 2. L-Box result

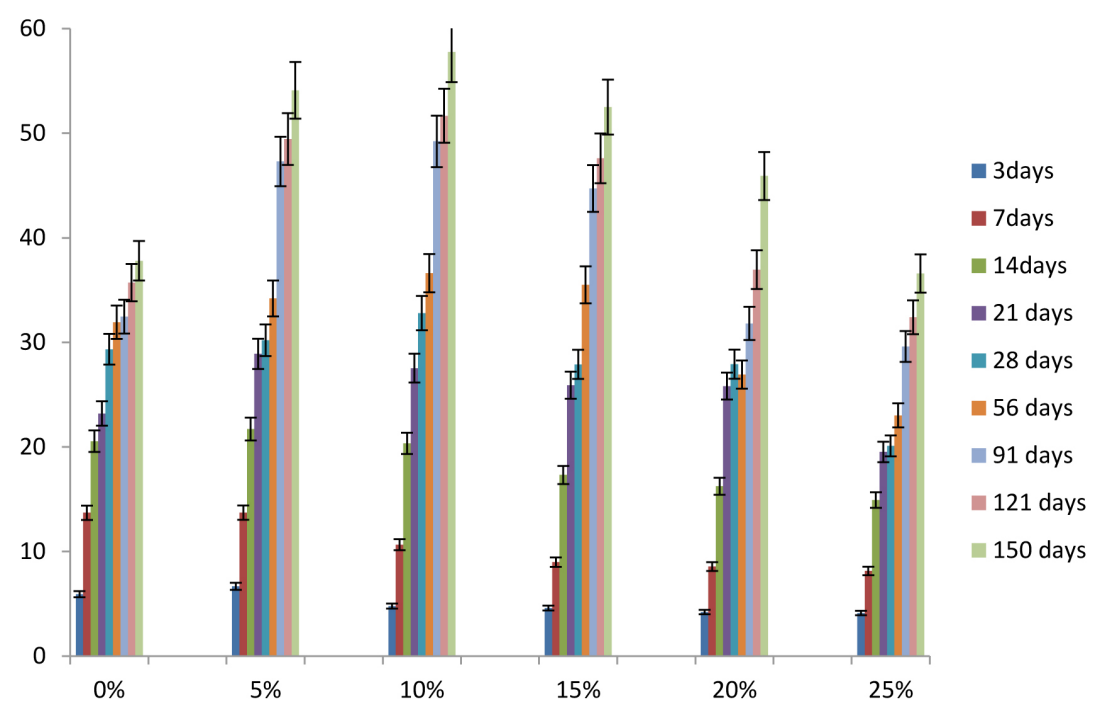

Figure 3. Compressive strength of dehydroxylated Kaolinitic clay versus age

Table 2. ANOVA for response surface quadratic model

\begin{tabular}{|c|c|c|c|c|c|c|}
\hline Source & $\begin{array}{l}\text { Sum of } \\
\text { Squares }\end{array}$ & DF & $\begin{array}{l}\text { Mean } \\
\text { Square }\end{array}$ & $\begin{array}{c}\mathrm{F} \\
\text { Value }\end{array}$ & Prob $>F$ & \\
\hline Model & 2074.283 & 9 & 230.4759 & 26.00548 & $<0.0001$ & significant \\
\hline A & 623.8372 & 1 & 623.8372 & 70.38995 & $<0.0001$ & \\
\hline B & 0.449426 & 1 & 0.449426 & 0.05071 & 0.8229 & \\
\hline C & 0.750283 & 1 & 0.750283 & 0.084657 & 0.7724 & \\
\hline$A^{2}$ & 472.1313 & 1 & 472.1313 & 53.27239 & $<0.0001$ & \\
\hline $\mathrm{B}^{2}$ & 0.008533 & 1 & 0.008533 & 0.000963 & 0.9754 & \\
\hline $\mathrm{C}^{2}$ & 0.006395 & 1 & 0.006395 & 0.000722 & 0.9787 & \\
\hline$A B$ & 38.7879 & 1 & 38.7879 & 4.376588 & 0.0422 & \\
\hline$A C$ & 46.28101 & 1 & 46.28101 & 5.222064 & 0.0272 & \\
\hline$B C$ & 0.000165 & 1 & 0.000165 & 1.86E-05 & 0.9966 & \\
\hline Residual & 389.9539 & 44 & 8.862589 & & & \\
\hline Cor Total & 2464.237 & 53 & & & & \\
\hline
\end{tabular}

strength increases as the Age of the concrete grows from 3 to 150 days. This is in agreement with the experimental results, as seen in Figure 2.

From the numerical optimization obtained as shown in the Figure 3, the maximum predicted compressive strength of $44.35 \mathrm{~N} / \mathrm{mm}^{2}$ was achieved under the optimum concrete formation of 110 days, Metakaolin of $52.73 \mathrm{~kg}$. The desirability of 1.00 was achieved with the numerical optimization performed, showing best accuracy of the developed model. 


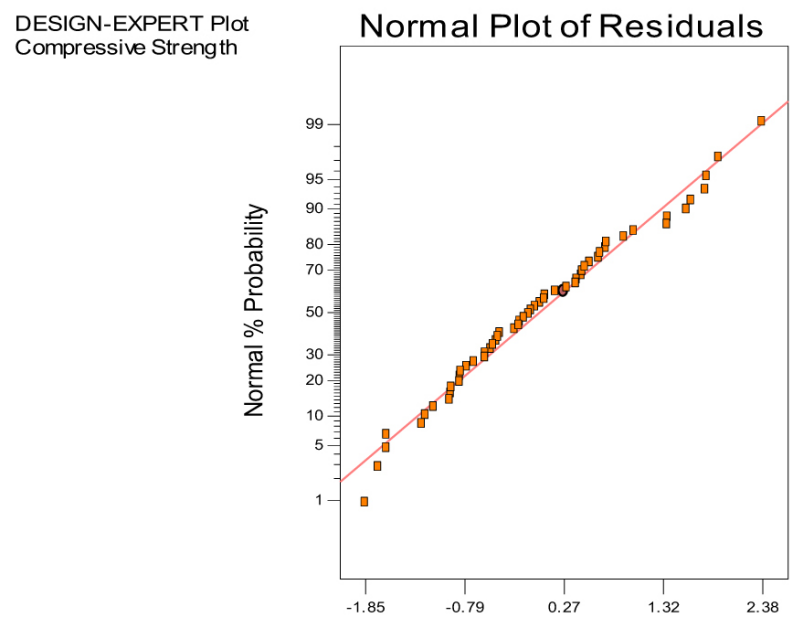

Studentized Residuals

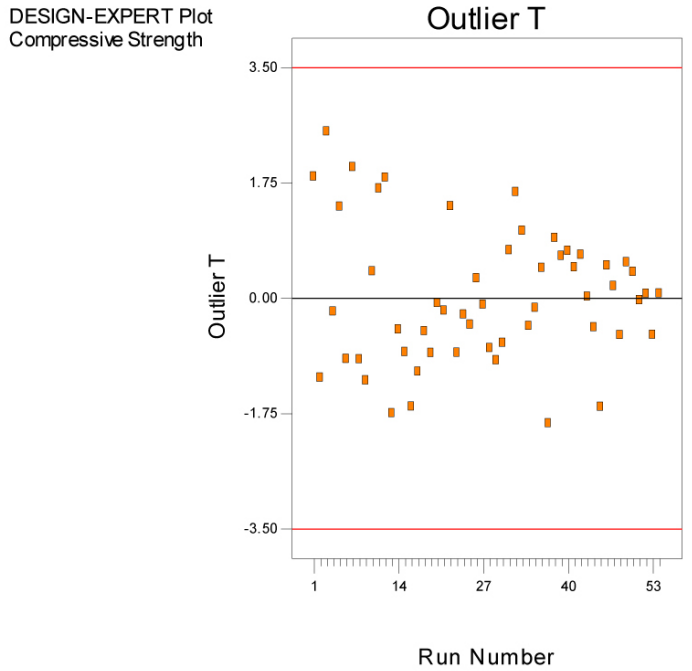

Run Number

Figure 4. Diagnostic plots of residuals and outlier against experimental runs

DESIGN-EXPERT PIOT Compressive Strength

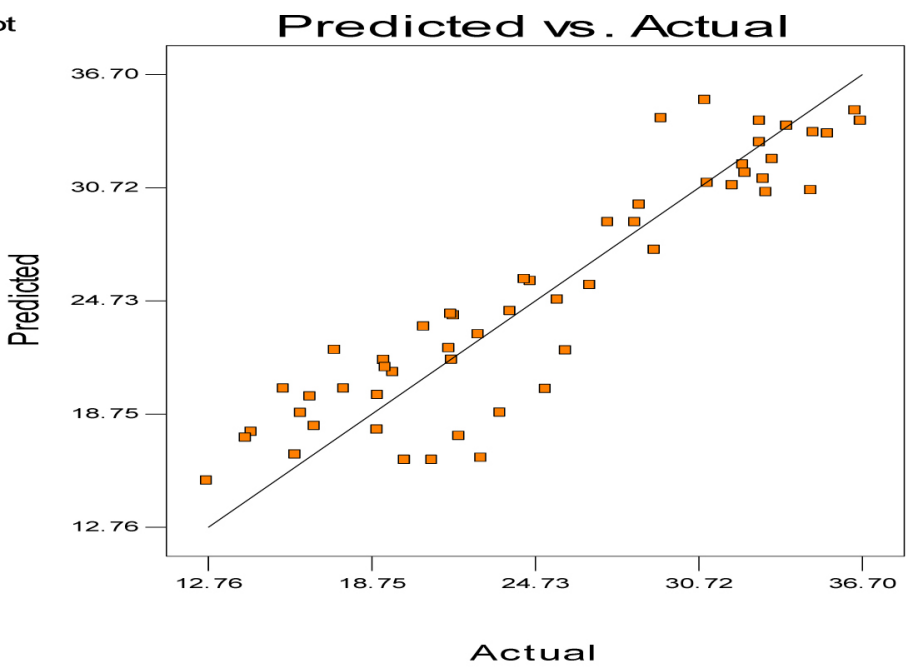

DESIGN-EXPERT PIOt

Compressive Strength $X=A:$ Age

$Y=B$ : Metakaolin

Actual Factor

C: W/C Ratio $=0.47$

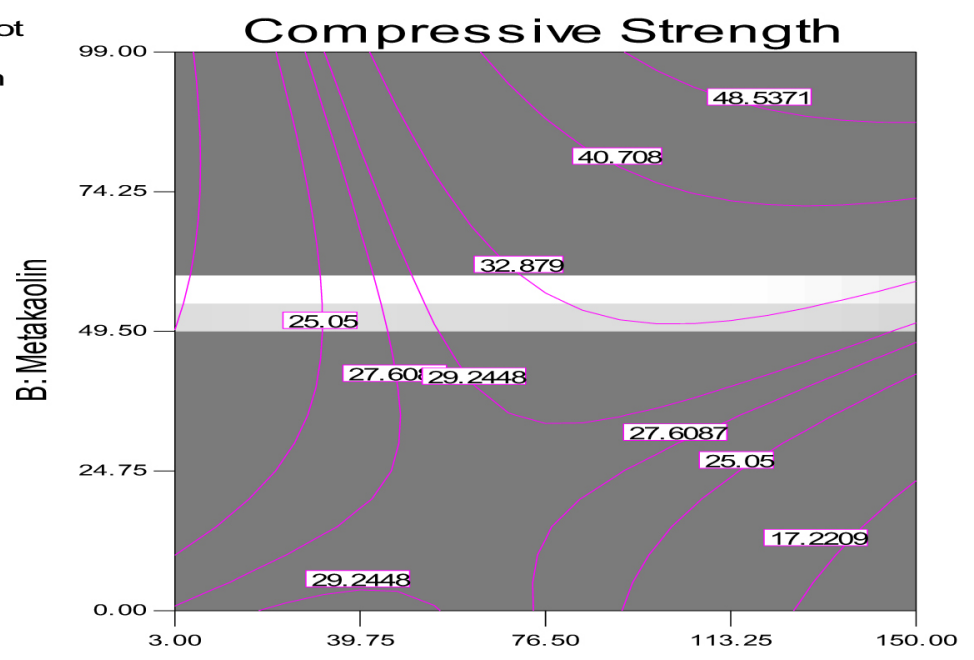

A: Age

Figure 5. Contour Plots of the Response Surface 


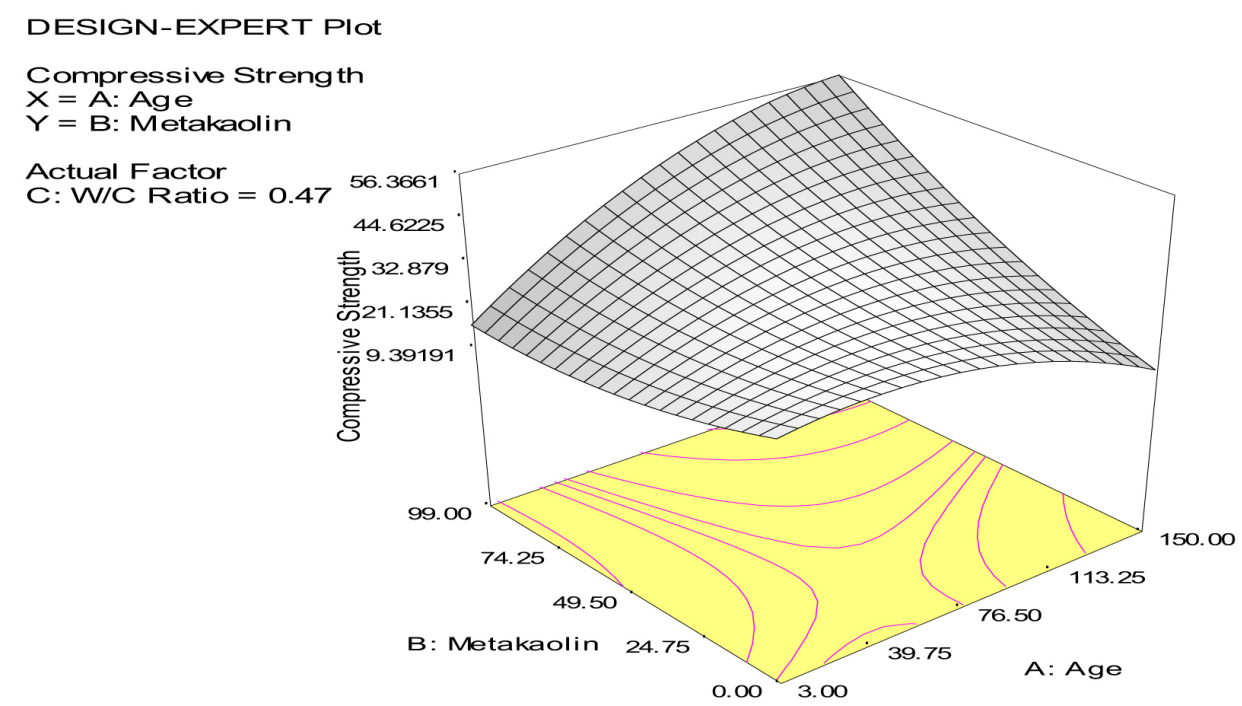

Figure 6. Response surface plots of Age and Metakaolin against the compressive strength

\section{CONCLUSIONS}

This research optimized the strength properties of metakaolin self-compacting concrete using response surface methodology. This was achieved using six concrete mixes by varying the proportion of metakaolin at $0 \%, 5 \%, 10 \%$, $15 \%, 20 \%$ and $25 \%$ respectively. The rheology and strength properties of the developed concrete were assessed at the fresh state and hardened state respectively. The result of the experimental analysis showed that the mix with the lowest T50 time is the SCC with no metakaolin addition. Additionally, from the numerical optimization obtained, the maximum predicted compressive strength of $44.35 \mathrm{~N} / \mathrm{mm}^{2}$ was obtained under the optimum concrete formation of 110 days, Metakaolin of $52.73 \mathrm{~kg}$. The age with the optimum concrete strength formation is 110 days with metakaolin addition of $52.73 \mathrm{~kg}$.

\section{Acknowledgements}

The authors are grateful to the management of Covenant University, Ota Ogun State and Nigeria Building and Road Research Institute, Ogun State for the previledge to use their Structural labouratory.

\section{REFERENCES}

1. Aggarwal P., Siddique R., Aggarwal Y., Gupta S.M. 2008. Self-compacting concrete procedure for mix design. Leonardo Electronic Journal of Practices and Technologies, 12, 15-24.

2. Akinoso R., Aboaba S.A. and Olajide W.O. 2011. Optimization of roasting temperature and time during oil extraction from orange (Citrus Sinensis) Seeds. A Response Surface Methodology Approach. African Journal of Food, Agriculture, Nutrition and Development 11(6).

3. Arikan M. et al. 2009. Properties of blended cements with thermally activated kaolin. Construction and Building Material 23(1), 62-70.

4. ASTM C192/C192M-16a. Standard practice for making and curing concrete test specimens in the laboratory. ASTM International, West Conshohocken, PA, 2016, www.astm.org

5. Badogiannis E., Papadakis V.G., Chaniotakis E., Tsivilis S. 2004. Exploitation of poor Greek kaolins. Strength development of metakoalin concrete and evaluation by means of k-value. Cement and Concrete Research 34, 1035-1041.

6. EFNARC 2002. Specification and Guidelines for Self-Compacting Concrete. February.

7. Grdić Z., Despotović I., Topličić-Ćurčić G. 2008. Properties of self-compacting concrete with different types of additives. Architecture and Civil Engineering 6(2), 173-177.

8. Hemant C. 2011. Effect of activated flyash in metakoalin based cement. Proceedings of the National Conference on Recent Trends in Engineering \& Technology 13-14 May, BVM Engineering College, Gujarat, India.

9. Hesami S., Hikouei I.S. and Emadi S.A.A. 2016. Mechanical behavior of self-compacting concrete pavements incorporating recycled tire rubber crumb and reinforced with polypropylene fiber. Journal of Cleaner Production, 133, 228-234. 
10. Jian-Tong D. and Zongjin L. 2002. Effects of metakoalin and silica fume on properties of concrete. ACI Materials Journal, July-August, 393-398.

11. Jiping B., Albinas G. 2009. Consistency of fly ash and Metakoalin concrete. Journal of Civil Engineering and Management 15(2), 131-135.

12. Justice J.M, Kennison L.H, Mohr B.J., Beckwith S.L, McCormick L.E, Wiggins B., Zhang Z.Z, and Kurtis K.E. 2005. Comparison of two metakoalins and a silica fume used as supplementary cementitious materials. Seventh International Symposium on Utilization of High-Strength/High Performance Concrete, Vol. 1-2, June, SP228-17.

13. Kamaruddin R. 1991. Application of Bamboo and Oil Palm Clinker in Lightweight Reinforced Concrete Beams. (Master of Science in the Faculty of Engineering), University Pertanian Malaysia.

14. Kong H. and Orbison J.G. 1987. Concrete deterioration due to acid precipitation. ACI Materials Journal, March-April, 110-116.

15. Labiran O. 2016. Nigerian metakaolin in concretes structures. Unpublished Thesis. Department of Civil Engineering. University of Ibadan, Nigeria.

16. Myers R.H. and Montgomery D.C. 1995. Response surface methodology; Process and product optimization using designed experiments. John Wiley and Sons, Canada.

17. Nabil M. 2006. Durability of metakoalin concrete to sulfate attack. Cement and Concrete Research $36,1727-1734$.

18. Navid R, Arash B., Belal A., Payam M., Birgani M. 2016. Durability and mechanical properties of selfcompacting concrete incorporating palm oil fuel ash. Journal of Cleaner Production 112, 723-730.

19. NIS 444-1.2003. Composition, specification and conformity criteria for common cements. Standards
Organisation of Nigeria.

20. Ogundiran M.B. and Ikotun O.J. 2016. Metakaolin - pozollanic material for cement in high strength concrete (www.iosrjournals.org).

21. Okamura H. and Ouchi M. 2003. Self-compacting concrete. Journal of Advance Concrete Technology $1(1), 5-15$.

22. Ouchi, M. and Hibino M. 2000. Development, Applications and Investigations of Self-compacting Concrete. International Workshop, Kochi, Japan.

23. Sabir B.B., Wild S., Bai J., 2001. Metakoalin and calcined clay as pozzolans for concrete .a review. Cement and Concrete Composite 23, 441-454.

24. Shepur N.S. 2014. Experimental study on strength of self compacting concrete by incorporating metakaolin and polypropylene fibre. IJERT.

25. Shivram B., Nagesh P. 2007. Early High Strength Concrete. Advantages and Challenges. CE\&CR, July, 38-41.

26. Tarun R., Naik R.K. 2012. Development of highstrength, economical self-consolidating concrete. Construction and Building Materials, 463-469.

27. Uygunoglu T., Topçu I.B. 2005. Influence of aggregate type on workability of selfconsolidating lightweight concrete (SCLC). Magazine of Concrete Research 63(1), 1e12.

28. Vejmelková E., Pavlíková M., Keppert M., Keršner Z., Rovnaníková P., Ondráček O., Sedlmajer S., Černý R. 2010. High performance concrete with Czech metakoalin. Experimental analysis of strength, toughness and durability characteristics. Construction and Building Materials 24, 1404-1411.

29. Walpole R., Myers R., Myers S., Ye K., 2007. Probability and Statistics for engineers and scientist. Prentice Hall, Upper Saddle River, NJ, 8th edition. 